\title{
Influence of Training, Working Environment and Work Discipline on the Performance of Millenial Employees
}

\author{
Dewi Sabita*, Endah Nuraini \\ Sekolah Tinggi Manajemen PPM \\ Jakarta, Indonesia \\ *dewibita@gmail.com
}

\begin{abstract}
This study aims to determine the effect of training, work environment and work discipline on the performance of millennial generation employees. Data collection techniques using a questionnaire distributed to 208 millennial generation employees. This research is quantitative by using multiple linear regression analysis. Data analysis methods used in this study are validity test, reliability test, classic assumption test, multiple linear regression analysis, $T$ test, $F$ test, and $R$ test using SPSS (Statistical Package for the Social Sciences). Based on the results of the analysis conducted, it can be concluded that training has an influence on employee performance, this can be seen from the results of $t$ arithmetic (8.872)> t table $(2,353)$. In the work environment a positive effect on employee performance, this can be seen from the results of $t$ arithmetic $(9,981)>t$ table $(2,353)$. Work discipline has a positive effect on employee performance, it can be seen from the results of $t$ arithmetic $(5.858)>t$ table $(2,353)$. The results of data analysis show that simultaneous training, work environment and work discipline influence employee performance with a determination coefficient $R 2$ of 0.822 meaning 82 percent of employee performance is affected by training, work environment and work discipline and the remaining 18 percent is influenced by other factors not included in the research model.
\end{abstract}

Keywords-influence; training; working environment; work discipline; performance; millenial employees

\section{INTRODUCTION}

In this globalization era, the competition is getting tougher; including the competition in the business world. Human resources have a very important role and also a contributing factor in the success of a company to achieve a predetermined target. In order to continuously improve the capabilities of each employee, it is necessary to hold the addition of science in the form of training and to improve the quality management of human resources that is by observing the competence of all employees and see the effectiveness of the training that has been given. At this time, training is an important factor to improve efficiency and effectiveness within the organization. Training is important thing to improve employee skills.

Performance is important thing because it's related to achieving the objectives of the company. This will be achieved in the event of success in carrying out the work tasks provided by the company. The success of all work tasks provided by the company is determined by the availability of qualified Human Resources.
Not only had the improvement of the quality of Human Resources, the company also required to continue to increase the competitiveness through improved management quality. Therefore, in order for the company to grow optimally, the maintenance of relationships that are aligned and sustainable with the employees is very important. In maintaining relationships with its employees, there is also a service provided by the company to support the work activities of employees, such as the holding of training and a comfortable work environment.

The comfortable working environment factor is also considered to be one of the considerations of employees in the work. When working, employees gain influence from their environment. If the working environment does not support employees to feel comfortable in working, the employees will certainly look for alternatives working elsewhere that may be more comfortable for him. The atmosphere in place works like relationships with fellow employees.

Working discipline is crucial for organizational growth, especially to motivate employees to discipline themselves in carrying out their work. Working discipline as the ideal state in supporting the performance of the work that must be adjusted to the rules in order to support the work optimisation, the higher level of discipline that the employee has, also the higher performance level that has a good impact to the company and it reflects a good sense of responsibility to the tasks that have been given.

Today, there is a new wave in the pattern of life; the waves come from more young children who are advancing and contributing to the future of all. From the research by Price Waterhouse Cooper in 2017, the percentage of workers globally will be dominated by millennials by $50 \%$ in the coming year of 2020. This happens in various fields, such as technology, food until entertainment [1].

In demographic groups are distinguished into 4 generations, namely Baby boomers, Generation X (Gen-Xer), Millennial Generation and Z-Generation. The millennial generation is a generation born between 1981 and 2000, or currently 15 to 34 years of old. While the data sourced from Cohorts in The Urban Middle Class Millennial shows the 2020 millennial generations are at the range of 20 years to 40 years [2]. This age is the productive age that will be the backbone of Indonesia's Economic. 
According to the study of Central Bureau of Statistics shows that many millennials are working, and also many companies are employing millennial generation as their employees [3]. Nowadays, millennials still need training in the areas where they work. For improving the capabilities of employees, millennial generations always develop their knowledge in training and structured program that related to training that makes improve the capabilities and abilities of Human Resources. A training effectiveness makes the deciding factor on whether the training is given regularly and suitable with the needs of each employee.

Millennials wants to meet with a lot of people, face-to-face training, and work with colleagues who have a lot of knowledge. Millennial generations will easily move the workplace if they don't fit their passion or expectations. Deloitte's annual millennial survey found that 43 percent of millennial employees are planning to leave their work now in the next 2 years. The main thing that inhibits business development is the employee's performance, especially young employees and belongs to millennials. Millennials are groups of employees with low employment loyalty rates than their predecessors. A survey conducted by a career and business consultant company, Gallup, found that the millennial employees most frequently came out the company. Boredom, saturation, and lack of appreciation become the reason of employees choose to quit employment

The number of millennial generations that meet the workforce, millennial generations needs to conduct training in order to improve the quality of human resources with the goal of improving performance in their respective companies. Millennial generations certainly require a comfortable environment to be able to achieve the targets they have set. A comfortable environment surely needs rules that do not burden the employee. If they do not get it, it can cause them to get bored and less loyal to the organization they work for. Based on the explanation above that the author has pointed out, the author is interested to conduct the research on the phenomenon with the thesis "Training effect, work environment and work discipline on the performance of millennial employees".

\section{RESEARCH OBJECTIVES}

The research is aimed to test and analyze the influence of 1) training on the performance of millennials ' employees; 2) Working environment on millennials ' performance; 3) Work discipline against performance; 4) Simultaneous training, work environment and discipline; to the performance of millennials ' employees

\section{LIBRARY OVERVIEW}

\section{A. Human Resource Management}

Human resource management is one of the strategic areas of the organization. Human resource management needs to be seen as an expansion of the traditional view to effectively manage the workforce and therefore requires knowledge of human behaviour and its managing ability.

According to Dessler, said that Human Resource Management is the process of obtaining, training, assessing and compensating employees, and also paying attention to employees ' working relationships, health and safety, and fairness issues [4]. Meanwhile, according to Bangun, Human Resource Management is a process, planning, organizing, preparing of staff, movement and supervision of procurement, development, compensation, reorganization, maintenance and separation of labour to achieve organizational objectives [5]. From the above definitions can be concluded that human resource management is a process of planning, organizing, and employee training for the purpose of the company.

\section{B. Training}

According to Dessler, "Training is the process of teaching new or existing employees now, the basic skills they need to run their jobs" [6]. According to Saks and Haccoun, training was the acquisition of knowledge, skills and ability to improve performance in one's job at the time [7]. Development is the skill and the need to do the future job responsibilities.

According to Noe in his book "Employee Training and Development", training is a business that is planned to assist employees acquire knowledge, skills and behaviours, which relate to the job with the objective can be applied to the work while development is the education of personality and ability that helps employees work effectively for the company and in the future [8].

\section{Working Environment}

The working environment is one of the most important factors that can affect employees in completing their work; the work environment has involvement in social relations at work and also maintains the relationship between peer, employer and organization [9]. According to Alex S. Nitisemito defines the work environment as follows: "The work environment is everything there is around the workers that can affect it in carrying out tasks that are sacrificed" [10]. Febriani and Indrawati mention that the comfort and cleanliness of the working environment are important factors that affect employees to complete their work [11]. According to Sedarmayanti, suggests that a place that has a group in which there are several supporting facilities to achieve the company's objectives in accordance with the vision and mission of the company [12].

From some perceptive of the above, it can be concluded that the working environment is the physical factors that exist around the work that can affect the employees in carrying out the tasks charged to him.

\section{Working Discipline}

According to Thaief et al, The Working Discipline is the attitude and behaviour of the employee to comply with the prevailing regulations and adjust the organization which will be based on self-awareness [13]. According to Hasibuan states that discipline is the realization and willingness of a person to adhere to all applicable rules and norms [14]. In the opinion of Alex S. Nitisemito, discipline is an attitude of behaviour and manufacture in accordance with the rules of the company either written or unwritten [15]. 
Conclusions from some statement of the above means that discipline must be asserted by an organization. Without the support of discipline employees and companies is difficult to realize its objectives. So discipline is the key to the success of a company in achieving its objectives.

\section{E. Employee Performance}

Robbins and Coulter define performance as the end result of an activity done [16]. According to Mangkunegara, performance is the result of work in quality and quantity achieved by an officer in carrying out his duties in accordance with the responsibilities given to him [17]. According to Mathis and Jackson, employee performance is the contribution that employees give to companies that can be identified from employees ' work [18]. Performance is an explanation of a value to determining a habit of labour to make a contribution to whether it is negatively or positively whose goal is to achieve the organization's initial goals.

Based on some perspective from some experts about performance above, it can be concluded that performance is a result of quality and quantity of work achieved by employees in carrying out their duties to achieve organizational objectives.

According to Schuler and Jackson 2004, there are 3 types of employee performance criteria i.e., 1) Criteria based on its satisfactory nature on the personal characteristics of a person's employees. Loyalty, Reliability, Ability, Communication and Lead skills are traits that are often assessed during the assessment process [19]. This type of criterion concentrates on how a person, not an accomplished or unaccomplished person in his or her work; 2) Criteria based on behaviour focused on how the work is implemented. These criteria are important for work requiring interpersonal relationships; and 3) Criteria based on results, these criteria are increasingly popular with the increasingly transmitted productivity and international competitiveness. This criterion focuses on what has been accomplished or produced rather than how something is accomplished or produced.

According to Mangkunegara there are two factors that affect the employee's performance, namely the Ability and Motivation [17]. In psychologically, employee ability consists of potential ability (IQ) and Reality (knowledge + skill) ability. It means, employees who have an average IQ (IQ $110-120$ ) with adequate education for their position and skilled in working on their daily work will be easier to achieve the expected work performance. Therefore, employees need to be placed on jobs that fit their expertise.

Motivation is formed from the attitude of an employee in facing work situation. Motivation is a condition that moves a directed employee to achieve the objectives of the organization (work goals). Mental attitude is a mental condition that encourages employees to strive to achieve work performance to the fullest. The mental attitude of an employee should be a psychophysical ready attitude (attitudes mentally, physically, goals and situations). It means, an employee must be mentally prepared, physically able, understand the main objectives and target work that will be achieved and able to utilize and create a work situation.
According to Mathis and Jackson dimensions and performance indicators are Quantity, Quality, Timeliness and Effectiveness [18]. Quantity is measured from the perception of employees to the number of activities assigned and the outcome. Quality, it can be measured from employee perception of the resulting quality of work and the perfection of the task to the skills and capabilities of the employee. The results of work done are close to perfect or fulfil the expected objectives of the work. Timeliness, measured from employee perception of an activity completed from the beginning of time to output. Able to finish at a present time and maximize the time available for other activities and effectiveness is the maximum utilization of resources and time of the organization to increase profits and reduce losses. Attendance is level of employee attendance in the company can determine the performance of employees.

\section{F. Y Generation}

According to the Howe and Strauss the millennial generation is a generation born in 1982 until the year 2000 [20]. The millennial generation is the largest generation in history with approximately 79.8 million members, exceeding the number of Baby Boomers. The millennial generation is the latest generation that enters the workforce. Another generation considers the millennial generation to be a difficult-tounderstand generation and it has own stereotypes [21].

Millennials have considered that work to be fun and will do so responsibly without pressure. The $\mathrm{Y}$ generations do everything in a balanced, when the working hours are over, so they're done, and they need some other time to work with. Like vacationing with family and friends, because in working they prefer to work together [22].

\section{RESEARCH MODEL}

The hypothesis Model used in this study contained a free variable (x) and a bound variable (y). The free variables in this research are training; work environment and work discipline, while the bound variables are employee performance, such as Figure 1, below.

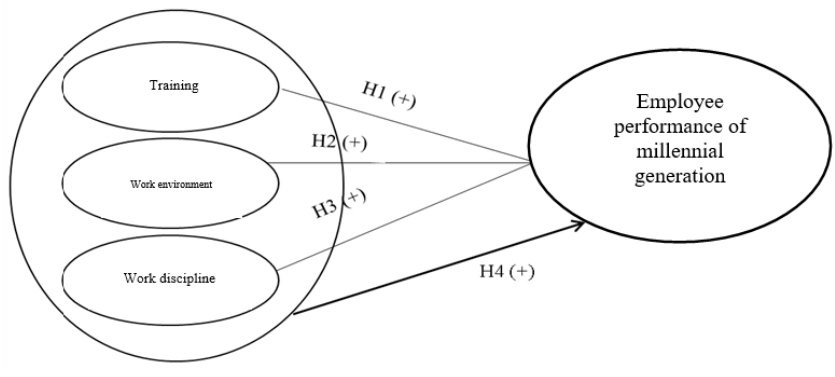

Fig. 1. Research model hypothesis.

Hypotheses are a temporary answer to the formulation of research issues. In this study can be formulated as follows:

\section{A. Hypothesis 1}

- Ho hypothesis: No training Influence (X1) on the millennial performance of a Millennial (Y) 
- H1: There is a training influence (X1) on the performance of a millennial (Y) generation employee.

\section{B. Hypothesis 2}

- Ho: No Work Environment influence (X2) on the millennial performance of a Millennial (Y)-generation employee:

- H2: There is an impact on the working environment (X2) on the performance of Millennial (Y) Generation employees

\section{Hypothesis 3}

- Ho: No influence on work discipline (X3) towards the performance of Millennial Employees (Y)

- H3: There is an influence of work discipline (X3) towards the performance of millennial employees $(\mathrm{Y})$

\section{Hypothesis 4}

- Ho: No influence Training (X1), Working Environment (X2), simultaneous work discipline (X3) against millennial employee performance (Y)

- H4: There is a training influence (X1), Working Environment (X2), simultaneous work discipline (X3) against the performance of a millennial generation employee (Y).

\section{RESEARCH METHODOLOGY}

This type of research is a quantitative study of analysis that explains the effect of free variable numb (x) to the bound variable (y) based on the results of the employee's view of the factor in accordance with what is happening at this time. Then, the results of the employees' views are compared to the conditions applied by researchers based on previous data support and theories related to those variables.

\section{A. Data Source}

The source of the data used to be research at this time is the employees or officers who belong to the Millennial generation. The population which is used as research is the employees or officers who belong to the millennial generation (generation Y) with a population of 208 people.

\section{B. Variable Operational Research}

According to Griffin and Moorhead, variable operationalization is a process of identifying scale measurements to assess the variables examined [23]. There are four variables used in this study, namely Training Variables (X1), Work Environment (X2), Work Discipline (X3) and Employee Performance (Y). The research instruments use questionnaires, and are compiled with Ordinal scales that are transformed into Interval scales.

Questionnaires were submitted using Likert scales including the numbers 1 to 5 . The Ordinal data is transformed into Interval data to satisfy some of the terms of the parametric analysis where the data at least the Interval scale. The following operational variables are in the table 1.

TABLE I. VARIABLE OPERATIONS

\begin{tabular}{|c|c|c|c|c|}
\hline \multirow{2}{*}{ Variable } & \multirow{2}{*}{ Variable Concept } & \multirow{2}{*}{ Dimension } & \multicolumn{2}{|l|}{ Measure Scale } \\
\hline & & & Indicator & Scale \\
\hline \multirow[t]{5}{*}{$\begin{array}{l}\text { Training } \\
\text { (X1) }\end{array}$} & \multirow[t]{5}{*}{$\begin{array}{l}\text { The process of teaching } \\
\text { new or existing } \\
\text { employees now, the } \\
\text { basic skills they need to } \\
\text { run their jobs. }\end{array}$} & Instructure & $\begin{array}{l}\text { Adequate qualifications/complencies } \\
\text { Motivate participants } \\
\text { Feedback needs }\end{array}$ & Likert \\
\hline & & Audience & $\begin{array}{l}\text { Passion for training } \\
\text { Desires to understand }\end{array}$ & \\
\hline & & Material & $\begin{array}{l}\text { Material accuracy with the purpose } \\
\text { Adding capabilities }\end{array}$ & \\
\hline & & Method & $\begin{array}{l}\text { Training methods according to the type of training } \\
\text { Conformity of methods with effective material }\end{array}$ & \\
\hline & & Objective and Goals & $\begin{array}{l}\text { Trainees' skills } \\
\text { Participants' understanding }\end{array}$ & \\
\hline
\end{tabular}


TABLE II. ADVANCED VARIABLES OPERATIONAL TABLE

\begin{tabular}{|c|c|c|c|c|}
\hline \multirow{2}{*}{ Variable } & \multirow{2}{*}{ Variable Concepts } & \multirow{2}{*}{ Dimension } & \multicolumn{2}{|l|}{ Measure Scale } \\
\hline & & & Indicator & Scale \\
\hline \multirow[t]{6}{*}{$\begin{array}{l}\text { Working Environment } \\
\text { (X2) }\end{array}$} & \multirow{6}{*}{$\begin{array}{l}\text { The working environment } \\
\text { is one of the most } \\
\text { important factors that can } \\
\text { affect employees in } \\
\text { completing their work, the } \\
\text { work environment has } \\
\text { involvement in social } \\
\text { relations at work and also } \\
\text { maintains the relationship } \\
\text { between associates, } \\
\text { superiors and } \\
\text { organisations. (Jain \& } \\
\text { Surinder, 2014) }\end{array}$} & $\begin{array}{l}\text { Phsycal } \\
\text { Environment: } \\
\text { Facility }\end{array}$ & $\begin{array}{l}\text { Facilities make employees feel comfortable in } \\
\text { working, so as to finish the job optimally. }\end{array}$ & \multirow[t]{6}{*}{ Likert } \\
\hline & & Temperature & $\begin{array}{l}\text { The human body always tries to maintain its } \\
\text { normal state. }\end{array}$ & \\
\hline & & Noise & $\begin{array}{l}\text { Crowded work environment can interfere with the } \\
\text { concentration in carrying out work }\end{array}$ & \\
\hline & & Interior & $\begin{array}{l}\text { The arrangement, coloring and cleanliness of each } \\
\text { room will affect the employees when doing the } \\
\text { work }\end{array}$ & \\
\hline & & $\begin{array}{l}\text { Mental Environment: } \\
\text {-Feeling Bored }\end{array}$ & $\begin{array}{l}\text { Lack of entertainment in work and lack of rotation } \\
\text { in work }\end{array}$ & \\
\hline & & $\begin{array}{l}\text { Social Environment: } \\
\text { - Relationship with } \\
\text { coworkers }\end{array}$ & $\begin{array}{l}\text { A group that employees must match the group's } \\
\text { expectations. Social relations in organizations, } \\
\text { Employees form an informal group that suits their } \\
\text { personality }\end{array}$ & \\
\hline \multirow[t]{4}{*}{$\begin{array}{l}\text { Working Discipline } \\
\text { (X3) }\end{array}$} & \multirow{4}{*}{$\begin{array}{l}\text { Work disciplines are the } \\
\text { attitudes and behaviors of } \\
\text { employees to comply with } \\
\text { applicable regulations and } \\
\text { adjust the oraganization that } \\
\text { will be based on self- } \\
\text { awareness (Thaief et al, } \\
2015)\end{array}$} & $\begin{array}{l}\text { Attendance and } \\
\text { Timelineness }\end{array}$ & $\begin{array}{l}\text { Office attendance on weekdays and timeliness of } \\
\text { work divided into the number of attendance } \\
\text { attendance, work-timely and correct. }\end{array}$ & \multirow[t]{3}{*}{ Likert } \\
\hline & & $\begin{array}{l}\text { Regulatory } \\
\text { Compliance }\end{array}$ & $\begin{array}{l}\text { The obedience and compliance of employees in } \\
\text { carrying out orders from the employer and the } \\
\text { prescribed order, the compliance of employees in } \\
\text { the use of the completeness of uniform clothing } \\
\text { that has been assigned by the organization or } \\
\text { company. }\end{array}$ & \\
\hline & & $\begin{array}{l}\text { Obedience to } \\
\text { working standards }\end{array}$ & $\begin{array}{l}\text { Employees'obedience to work in accordance with } \\
\text { the company's prescribed procedures, employees } \\
\text { undertake all occupations according to the } \\
\text { company's predetermined work standards }\end{array}$ & \\
\hline & & Work Ethic & $\begin{array}{l}\text { The ability of Employees in the company, to adjust } \\
\text { to the environment, to maintain good relations } \\
\text { with one another. }\end{array}$ & \\
\hline \multirow[t]{4}{*}{$\begin{array}{l}\text { Employee Performance } \\
(\mathrm{Y})\end{array}$} & \multirow[t]{4}{*}{$\begin{array}{l}\text { Employee performance is a } \\
\text { contribution that employees } \\
\text { give to companies that can be } \\
\text { identified from employee work } \\
\text { (Mathis \& Jackson, 2006) }\end{array}$} & Work Quality & $\begin{array}{l}\text { Measured from employee perception of the } \\
\text { resulting quality of work and the perfection of the } \\
\text { task of the employee's skills and abilities. }\end{array}$ & Likert \\
\hline & & Work Quantity & $\begin{array}{l}\text { Measured by employee perception of activity } \\
\text { amount }\end{array}$ & \\
\hline & & Timelineness & $\begin{array}{l}\text { Measured from employee perception of an activity } \\
\text { completed from the start until become an output }\end{array}$ & \\
\hline & & Effectiveness & $\begin{array}{l}\text { Maximum utilization of resources and time of the } \\
\text { organization to increase profits and reduce losses }\end{array}$ & \\
\hline
\end{tabular}




\section{Data Collection Methods}

In conducting data collection, there are several ways: library study and spread questionnaire. The study was conducted by reading several literature books, journals, internet and others related to Human Resource Management.

Beside library studies, researchers distributed questionnaires to respondents in the form of pre-millennial generation samples. Questionnaires were disseminated by drafting questions that could describe the views of millennial employees in relation to the influence of training, working environment and work discipline towards employee performance. According to Sekaran and Bougie a questionnaire is a series of pre-formulated written questions that answer respondents, a somewhat closer alternative [24]. Statements or questions in the questionnaire are measured using the Likert scale type. According to Sugiyono the scale of Likert is used to measure the attitudes, opinions and preconception of a person or group of people about social phenomena [25].

The questionnaire was made by sampling 208 millennial employees. With the questionnaire distributed through a partner domiciled in Jabodetabek through Google Form with the age that has been adjusted to the target researchers.

\section{Data Processing Techniques}

In this study, data processing techniques are a Descriptive Statistic approach through measurement of central symptoms which include average, median and mode, and size of spread or variability by using standard deviation and range scores. In the process of Data analysis obtained will be processed using the application Statistical Package for the Social Sciences (SPSS). SPSS is a computer application to manage statistical data with a fast and precise process, making the results in accordance with the desired decision makers.

\section{E. Research Samples}

Sampling is the process of owning or selecting and obtaining information on a population by researching some of the existing samples as the basis of estimates/predictions and for detecting unknown information [26,27]. According to Salkind, the population is a group/whole entity that wants to be researched/concluded [27]. He also said that samples were widely used for research purposes; this is because most researchers do not have the necessary resources such as time, cost or access to measure or observe the object/population to be researched, then substitution of objects.

The population is perceived to be the right choice. Samples are part of the population and can represent the entire population studied [27]. The study uses non-probability sampling techniques, where in non-probability sampling techniques, samples are randomly selected based on researchers ' assessment to select existing samples and samples without the knowledge of researchers whether selected samples represent the entire population being researched [26,27]. The types of probability sampling used in this study are convenience sampling. Because in this method, sampling is obtained based on the preference and ease in obtaining the respondent and reduce the cost so that it is cheaper when compared to other sampling techniques [26]. The population in this research is an employee of millennials

\section{F. Regression Analysis}

According to Priyatno, multiple linear regression analyses are used to determine the influence or linear relationship between two or more independent variables with one dependent variable [28]. In this study, the regression equations used in conducting regression analyses were as follows:

$$
\mathrm{Y}=\mathrm{a}+\mathrm{b}_{1} \mathrm{X}_{1}+\mathrm{b}_{2} \mathrm{X}_{2}+\mathrm{b}_{3} \mathrm{X}_{3}
$$

Description:

- $\mathrm{Y}=$ Employee Performance

- $\quad \mathrm{a}=$ Predictor coefficient

$\mathrm{b}_{1} \mathrm{~b}_{2} \mathrm{~b}_{3}=$ Variable Independent Regression Coefficient:

- $\mathrm{X}_{1} \quad=$ Training

- $\mathrm{X}_{2} \quad=$ Work Environment

- $\mathrm{X}_{3} \quad=$ Work Discipline

\section{G. Partial Significance Test (Test T)}

According to Priyatno, test $\mathrm{T}$ is used to know the truthfulness of statements or allegations that are hypothesized [28]. To know the effect of free variables against dependent variables, then test $\mathrm{T}$. Test criteria on Test $\mathrm{T}$ are as follows:

- If significance is $>0.05$, then Ho is accepted

- If significance is $<0.05$, then Ho is rejected.

\section{H. Simultaneous Test of Significance (F statistical test)}

Test Anova or test $\mathrm{F}$ i.e. the regression coefficient test together to test the significance of the influence of some independent variables against dependent variables. According to Priyatno [28], the testing criteria on test Anova or test F is as follows:

- If $\mathrm{F}$ count $\leq \mathrm{F}$ table then $\mathrm{H} 0$ received.

- If $\mathrm{F}$ counts $>\mathrm{F}$ table then $\mathrm{H} 0$ is rejected.

And for knowing the simultaneous influence of variables based on the significance values are as follows:

- If the significance of $>0.05$ then H0 accepted, there is no significant influence.

- If the significance of the $<0.05$ then H0 rejected, there is a significant influence.

\section{Coefficient of Determination (R2)}

According to Priyatno, Adjusted $R$ Square shows the contribution of free variable influence to the bonded [28]. Adjusted $R$ Square to measure donations of influence if in regression use more than two free variables. This numbers is 
then converted to a percent form, which means the donation percentage, influences the variable independent of the bound variable.

\section{RESULTS OF RESEARCH AND DISCUSSION}

In this chapter, the results of analysis and discussion of respondents' opinion relating to variables in this research include: training, working environment and working discipline. In the form of hypothesis analysis using multiple linear regression.

\section{A. Multiple Linear Regression Analyses}

Based on multiple regression results using SPSS program 24 obtained results as follows:

The linear regression equation formed is:

$$
Y=0,371 X_{1}+0,413 X_{2}+0,251 X_{3} .
$$

Description: Y: Employee Performance; $\mathrm{X}_{1}=$ Training; $\mathrm{X}_{2}=$ Work Environment; and $\mathrm{X}_{3}=$ Work Discipline. From the above equation can be explained that:

- Variable training, work environment and work discipline have a coefficient direction positively towards employee performance.

- The training coefficient shows a positive value of 0.371 , which means that training is better to be given organization can improve employees' performance assuming other variable values are fixed

- The working environment coefficient shows a positive value of 0.413 , which means the working environment, is better given that the organization can improve the performance of employees assuming other variable values are fixed.

- The coefficient of work discipline shows a positive value of 0.251 , which means that the work discipline, is getting better given that the organization can improve employees ' performance assuming other variable values are fixed.

From the results of multiple linear regression tests can be deduced all three variables of the free (X) above positively affect the bound variable (Y).

\section{B. Hypothesis Test}

$\mathrm{T}$ test results on this research using SPSS 24 are as follows: For a training variable $(\mathrm{X} 1)$ the $\mathrm{T}$ value calculated is obtained at 8.872. The Working environment variable (X2) the $\mathrm{T}$ value calculated is obtained at 9.981 and the work discipline variable (X3) $\mathrm{t}$ calculated 5.858. Furthermore, the comparison of $\mathrm{T}$ calculated with $\mathrm{T}$ table where the level of trust (Confidence Interval) is $95 \%$ or alpha $=0.05$. T-table result of 2.353

The results of $\mathrm{T}$ calculate comparison with $\mathrm{T}$ table of the three free variables above is as follows:

- The training variables (X1) Unknown $\mathrm{t}$ calculate $(8.872)>\mathrm{T}$ table $(2.353)$ and Sig value $0.00<0.005$ so,
Ho's decision was rejected and $\mathrm{H} 1$ was accepted Training affects millennials ' employee performance.

- The Working environment variable (X2) is known as T calculate (9.981) > T table (2.353) and the value of Sig $0.00<0.005$ so, Ho's decision is rejected and $\mathrm{H} 2$ is accepted. Working environment (X2) affects the performance of millennial generation employees.

- The work discipline (X3) variable is known as T calculate (5.858) > T table (2.353) and the value of Sig $0.00<0.005$ so, Ho's decision is rejected and $\mathrm{H} 2$ is accepted. Compensating (X3) affects the performance of millennial generation employees.

From the comparison that has been outlined above can be supposed that the hypothesis $\mathrm{H} 1, \mathrm{H} 2$ and $\mathrm{H} 3$ are acceptable. Which is in each free variable affects the variables bonded individually with positive effect on the bound variable.

The $\mathrm{F}$ test results in this study using SPSS 24 indicate that the value of $\mathrm{sig}=0.000<0.05$, can be deduced $\mathrm{H} 0$ rejected or $\mathrm{H} 3$ received, which means independent variables together/simultaneously have a significant effect on the dependent variables. The results showed that training, work environment and work discipline showed influence on the performance of Millennial employees. This is the positive response that the millennial employee responses to training, working environment and the greater the working discipline that the millennial employee has, the employee performance will be better.

\section{Coefficient Determination Test Result (test $R$ )}

The result of coefficient of determination test using SPSS 24 obtained R2 (R Square) value of 0.825 . It means, variable training (X1), Work Environment (X2) and work discipline (X3) affect employee performance variables (Y) as $82.50 \%$ while the remaining $17.50 \%$ are influenced by other independent variables not included in this study.

\section{DISCUSSION}

This research proves that training and development have an influence on employee performance. This is aligned with the opinion of Chaeril et al who said that training can improve employee performance [29].

The research also proves that the work environment has an influence on employee performance. This is aligned with the opinion of Khaled Al-Omari and Haneen Okasheh explaining that situational constraints consist of factors such as noise, office furniture, ventilation and light, are the main environmental conditions that have a negative impact on the performance of the work and should get more attention to competitive compensation and worth [30].

This research proves that working discipline has an influence on employee performance. This is aligned with Valensia's opinion Angelina Wisti Dapu which explains the work discipline affecting employee performance. Work disciplines are positive and significant to the employee's performance [31]. 
From previous research results, in previous studies, no research objects were categorized into millennial generations (Gen Y). Therefore, the research is expected to increase in training, working environment and work discipline to the performance given by the millennial employees, the better the performance of the millennial employees.

Based on the supporting theory, data processing, and the results of the discussion that can be done by the millennial employees to improve performance in managerial policies are expected to provide feedback on management practices.

Some implications can be derived from the results of this study as follows: Research shows that training conducted by an organization has an influence on employee performance. Based on the results of the study, employees are expected to conduct instructor selection, training material form to suit the needs and interests of employees.

The results of the study demonstrate that the work environment has an influence on employee performance, especially working atmosphere and supported by adequate working facilities. If the working environment is noisy or crowded, it can interfere with the concentration in working. Therefore, noise control in the working environment is very important to create a comfortable working atmosphere that can support good work.

According to Thaief et al based on the dimension of work discipline divided into 4 scale assessments and from research results, especially the scale of regulatory compliance and adherence to the working standards have an influence on employee performance [13]. So, that it can be concluded that there is still a lack of disciplinary attitude from the millennial generation, which must be done by the organization is an assertive attitude in giving sanctions when employees violate the rules, and for the millennial employee is necessary to be a conscious attitude of the company's regulations and obey to create a good image for the millennial employees themselves.

\section{VIII.CONCLUSIONS AND SUGGESTIONS}

\section{A. Conclusion}

This research aims to determine the influence of training, work environment, and work discipline on the performance of millennials' employees. Based on the analysis and results of the research that has been done, it can be concluded as follows:

The results of the research showed, 1) There is a significant influence between training on the performance of millennials' employees; 2) There are significant influences between the working environment on the performance of millennials' employees; 3) There is a significant influence between working discipline on the performance of millennials' employees; 4) There is a positive influence on training, working environment and working discipline jointly towards the performance of the millennial generation employees.

\section{B. Suggestions}

Based on the conclusion above, there are some suggestions that can be input for millennials' employees in relation to the influence of training, working environment and working discipline on employee performance,

From the results of the research that has been done, training has a positive influence on the performance of millennials employees, so the training should be kept so that employees can improve their performance. This can be done by providing coaches or instructors who are reliable and more experienced so as to give employees the employee, provide the training methods and materials that employees need to improve their performance.

In work environment needs to be enhance the comfortness and cleanliness of the work environment, such as the arrangement of regular space, adequate facilities and lighting, so as to create a conducive work environment and needs to be held a sound-proof room, so employees can focus on their respective work.

Meanwhile, in discipline needs to be improved in the organization in the form of assertive action, such as reprimand in both oral and non-verbal forms and need to have a sense of awareness in employees to comply with the regulations of an organization. Before a strike was held, firstly, socialization was conducted to the employees to understand the rules of his company. From those three suggestions are aimed to improve the performance of the millennial employees.

The variables used for this study are quite of 3 variables, while there are many other variables that can be researched. Therefore, further studies are expected to add more variables. This aims for making the results more complex and can provide a broader picture of what factors can affect the performance of the employees.

\section{REFERENCES}

[1] www.whiteboardjournal.com

[2] C. Cohorts, The Urban Middle Class Millenial). Alvara Research Center, 2016

[3] Central Bureau of Statistics, The Urban Middle Class Millenial. Alvara Research Center, 2016.

[4] D. Dessler, Manajemen Sumber Daya Manusia Human Reources, Jilid 2. Jakarta: Prenhalindo, 2013.

[5] W. Bangun, Manajemen Sumber Daya Manusia. Jakarta: Erlangga, 2012.

[6] G. Dessler, Manajemen Sumber Daya Manusia. Edisi 9. Jilid 1. Jakarta: Kelompok Gramedia, 2004.

[7] A.M. Saks and R.R. Haccoun, Managing Performance Through Training and Development. Fifth Edition. Toronto: Nelson Education Ltd, 2010.

[8] R. Noe, Human Resource Management. Gaining Competitive Adventages $3^{\text {rd }}$ Edition. Mc Graw Hill, 2010.

[9] R. Jain and S. Kaur, "Impact of Work Environment on Job Satisfaction," International Journal of Scientific and Research Publication, vol. 4, no. 1, pp. 1-8, 2014

[10] A.S. Nitisemito, Manajemen Personalia. Edisi Revisi. Penerbit Ghalia, 2002.

[11] T. Febriani and D. Indrawati, "Pengaruh Motivasi, Kompensasi serta Lingkungan Kerja Fisik terhadap Kinerja Karyawan Hotel The Niche Bali,” E- Jurnal Manajemen Universitas Udayana, vol. 2, no. 5, pp. 541551,2013

[12] S. Sedarmayanti, Manajemen Sumber Daya Manusia. Bandung: Refika Aditama, 2013. 
[13] I. Thaief and A. Baharuddin, "Effect of training, compensation and work discipline against employee job performance," Rev. Eur. Stud., vol. 7, no. $23,2015$.

[14] H. Malayu and S.P. Hasibuan, Manajemen Sumber Daya Manusia. Jakarta: PT Bumi Aksara, 2007.

[15] A.S. Nitisemito, Manajemen Personalia. Jakarta: Ghalia Indonesia, 1992.

[16] S.P. Robbins and M. Coulter, Principles of management. Translated by Seyyed Mohammad Arabi and Mohammed Ali Hamid Rafiee and Behrouz Asrari Ershad, Fourth Edition, Tehran: Office of Cultural Studies, 2007.

[17] A.A. Anwar Prabu Mangkunegara, Manajemen Sumber Daya Manusia Perusahaan. Bandung: Remaja Rosdakarya, 2009.

[18] R.L. Mathis and J.H. Jackson, Human Resource Management: Manajemen Sumber Daya, 2006.

[19] S. Schuler and J. Jackson, Manajemen Sumber Daya Manusia, Menghadapi Abad Ke-21. Edisi Ke-Enam. Jakarta: Erlangga, 2004.

[20] N. Howe and W. Strauss, Millennials Rising. New York: Vintage Books, 2000.

[21] Robert Half International, What Millennial Workers Want: How to Attract and Retain Gen Y Employees. California: Robert Half International, 2008.

[22] L. Lancaster and D. Stillman, When Generations Collide at Work: Managing Traditionalists, Baby Boomers, Generation Xers, and Millennials. HarperCollins, 2002.

[23] M. Millmore, Strategic Human Resources Management. UK Prentice Hall, 2007.
[24] U. Sekaran, Uma and R. Bougie, Research Methods for Business. United Kingdom: Jhon Wiley \& Sons Ltd, 2013.

[25] S. Sugiyono, Metode Penelitian Kuantitatif, Kualitatif dan R\&D. Bandung: PT Alfabet, 2016.

[26] D. Perumal, CMRM6103 RESEARCH METHODOLOGY/ GMRM5103 RESEARCH METHODS IN COMPETITIVE INTELLIGENCE. (A. Jameelah, Ed.) Open University Malaysia (OUM), 2010.

[27] N.J. Salkind, Encyclopedia of Research Design (Vol. 1). California, Thousand Oaks: Sage Publication, 2010.

[28] D. Priyatno, SPSS 22 Pengolahan Data Terpraktis.Yogyakarta: CV Andi Offset, 2014.

[29] C. Chaeril, A. Umar and M. Azis, "Pengaruh Kompetensi, Pelatihan Dan Pendidikan Terhadap Kinerja Pegawai Pada Kantor Badan Pengelola Keuangan Daerah Di Kabupaten Bantaeng," YUME: Journal of Management, vol. 1, no. 2, 2018.

[30] K. Al-Omari and H. Okasheh, "The influence of work environment on job performance: A case study of engineering company in Jordan," International Journal of Applied Engineering Research, vol. 12, no. 24, pp. 15544-15550, 2017.

[31] V.A.W. Dapu, "The influence of work discipline, leadership, and motivation on Employee performance at PT. Trakindo utama manado," Jurnal EMBA: Jurnal Riset Ekonomi, Manajemen, Bisnis dan Akuntansi, vol. 3, no. 3, 2015. 